\title{
Lubelska komisja Boni Ordinis i jej wpływ na rozwój przestrzenny miasta
}

\author{
Natalia Przesmycka ${ }^{1}$, Jerzy Z. Przesmycki ${ }^{2}$ \\ ${ }^{1}$ Politechnika Lubelska, Wydziat Budownictwa i Architektury, \\ Katedra Architektury, Urbanistyki i Planowania Przestrzennego, \\ e-mail: natalia.przesmycka@gmail.com \\ ${ }^{2}$ Wyższa Szkoła Przedsiębiorczości i Administracji w Lublinie, \\ e-mail: jerzy.przesmycki@gmail.com
}

Streszczenie: Działalność lubelskiej Komisji Dobrego Porządku była pierwszym dającym wymierne efekty działaniem mającym na celu poprawę wizerunku miasta i uregulowanie zagadnień administracyjno - urbanistycznych po zniszczeniu miasta spowodowanym XVII wiecznymi wojnami i upadkiem ekonomicznym. Działalność komisji była również przejawem oświeceniowej myśli społecznej i wzrostowi znaczenia mieszczaństwa w państwie.

Słowa kluczowe: Komisja Boni Ordinis, rozwój przestrzenny Lublina.

\section{Stan miast i pierwsze próby reform miejskich w Rzeczypospolitej}

Zubożenie i zrujnowanie Lublina w II połowie XVIII wieku nie było w skali kraju wyjątkiem. Odbudowa miast w Polsce po wojnach północnych odbywała się często z pominięciem norm prawa zwyczajowego i pisanego, wbrew wcześniejszym, sięgającym jeszcze czasów lokacji przywilejom i podziałom. U podstaw tych poczynań leżała samowola posesorów magnackich, szlacheckich i duchownych. W miastach królewskich, nad miastem sprawowali opiekę starostowie, którzy w arbitralny sposób mogli narzucać swą wolę władzom miejskim, jednak przede wszystkim mający na uwadze własne przychody. Zagadnienia ładu i estetyki miasta były najczęściej pomijane. Liczne w królewskich miastach jurydyki, stanowiły enklawy wyjęte spod praw magistratów.

Zubożenie mieszczaństwa oraz brak uregulowań prawnych i nadzoru budowlanego prowadziło do sytuacji, w której większość domów wznoszonych w odbudowujących się miastach, była wykonana z najtańszego materiału - drewna. Murowane budynki często kryto gontem, a domy drewniane strzechą, przy czym kominy nie zawsze były murowane z cegły, (wykonywano je jako sztangowe), co powodowało zagrożenie pożarowe. Dodatkowo w wielu miastach wśród gęstej zabudowy lokowano zakłady „przemysłowe” używające otwartego ognia. Często nie przestrzegano linii zabudowy ulic, doprowadzając w ten sposób do ich zawężenia. Nieład i nadmierne zagęszczenie zabudowy panował zwłaszcza w dzielnicach żydowskich.

Pierwsze tendencje do ingerowania państwa $\mathrm{w}$ kształtowanie rozwoju przestrzennego miast pojawiły się w Europie w XVIII wieku. Podjęcie państwowej 
polityki budowlanej wobec miast królewskich zapoczątkowało na sejmie konwokacyjnym stronnictwo Czartoryskich. Na sejmie tym zniesiono obowiązek udzielania przez mieszczan bezpłatnych kwater dla posłów i dygnitarzy i upoważniono miasta stołeczne województw do przejmowania pustych placów i domów, jeżeli pozostawały one bez właściciela przez okres co najmniej sześciu lat. Dało to podstawę dla odbudowywania finansów miast i porządkowania zabudowy.

Inicjatorem powstania Komisji Dobrego Porządku (Boni Ordinis) był król Stanisław August Poniatowski. Komisje miały na celu zapoznanie się z całością gospodarki miejskiej, zbadać stan finansów i zwrócić się do asesorii królewskiej z wnioskami. Komisje rozpoczęły działanie w 1765 roku dla Warszawy i Lwowa. Miało ich powstać 22. [Wróbel, 12]. W latach 1767-68 powołano Komisję Brukową dla Lwowa, Komisję Dobrego Porządku (Boni Ordinis) dla Warszawy, Wieliczki i Kamieńca Podolskiego. Komisje zajmowały się organizowaniem władz miejskich, uporządkowanie spraw finansowych i kwestii własnościowych. W wielu przypadkach Komisje podejmowały inicjatywę w zakresie porządkowania zabudowy miejskiej, reperacji bruków lub usuwania nieczystości. Należy zaznaczyć, że praca w komisjach była nieodpłatna. Dzięki pracom komisji miasta doczekały się dokładnych planów pomiarowych, sporządzanych przez zaprzysiężonych geometrów.

\section{Stan Lublina w XVIII wieku}

Po wojnach z drugiej połowy XVII wieku zmienił się charakter miasta. Lublin stał się miastem Trybunału Koronnego, szlachecko - kościelnym, o znaczeniu politycznym, miejscem obrad sejmikowych, sądów ziemskich i grodzkich. Mieszczańskie, handlowe i rzemieślnicze tradycje po potopie „zamarły”.

Można zaryzykować stwierdzenie, że położenie Lublina przy krzyżowaniu się szlaków komunikacyjnych, będące poprzednio czynnikiem rozwoju miasta, stało się teraz jego zgubą. W sumie szlakami tymi przemieszczały się siedem razy oddziały szwedzkie (1702-1704, 1706, 1709), zatrzymując się dwukrotnie na dłuższe postoje. Wojska koronne przebywały tu trzykrotnie na „leżach zimowych” (w latach: 17031708), wojska rosyjskie przebywały od 1704 do 1711 roku. Dwa lata później August II wprowadził tu wojska saskie, a w 1715 roku ponownie wkroczyły wojska rosyjskie, [Przesmycka E., 9]. W 1706 roku Lublin zajęły wojska cara pod dowództwem gen. Mienszykowa. W 1707 roku zwołano tu sejm mający zdetronizować króla, na który przybył sam Piotr I. Po zamknięciu obrad car opuścił miasto, ale pozostawił w Lublinie 8 tysięcy żołnierzy. Później w 1717 roku w mieście stacjonowali dragoni generała Schlippenbacha. Od tego momentu garnizony (wojsk okupanckich bądź własnych) stały się obecne w mieście.

Pobyt w mieście obcych lub własnych wojsk, oznaczał kontrybucje, albo przynajmniej utrzymywaniem stacjonujących tu żołnierzy na koszt mieszkańców.

Charakter własnościowy i administracyjny gruntów i placów miejskich nie był jednolity. Cały obszar miasta podlegał władzy administracyjnej magistratu, jednak wiele terenów będąc reliktem czasów feudalnych różniło się miedzy sobą pod względem prawnym. Były to pozostałości dawnych enklaw prawnych takich jak jurydyki, libertacje, oddzielne folwarki wyjęte spod prawa miejskiego.

Obszar miasta w drugiej połowie XVIII wieku obejmował: „miasto murowane”, ul. Krakowskie Przedmieście, ul. Dolną i Górną Panny Marii (dziś Podgrodzie 
i Narutowicza), Probostwo św. Mikołaja na Czwartku, Lemszczyznę (Bursaki), Sierakowszczyznę, Kalinowszczyznę, Białkowska Górę, Słomiany Rynek, Podzamcze, Ponikwodę, Tatary (po lewej stornie Bystrzycy) i Piaski (również część leżącą po prawej stronie Bystrzycy). Do miasta należał również folwark i wieś [5]. Były to tereny bardzo zróżnicowane pod względem zurbanizowania i ukształtowania terenu. W przeważającej części, z wyjątkiem Starego Miasta, były to tereny pagórkowate bądź podmokłe, dotychczas słabo zaludnione i trudne do zagospodarowania. Pod względem administracyjno - prawnym z układu miejskiego można było wyodrębnić około 30 jurydyk [7].

Dopiero Uchwała Konstytucji 3 Maja zniosła jurydyki świeckie i duchowne w miastach. Magistrat lubelski podporządkował sobie urzędy wójtowsko-ławnicze części ówczesnych jurydyk, [7]. Również Sejm Grodzki w 1793 roku w ustawie „Miasta Rzeczypospolitej” znosił jurydyki szlacheckie i duchowne, ale nie wspominał o jurydykach skarbowych, zaś teren miast uznał „od pierwszego numeru domów do ostatniego z przedmieść za jedno miasto”, [6]. Dodatkowo w 1791 roku mieszczanie uzyskali możliwość likwidacji jurydyk, przez co doszło do zjednoczenia prawie wszystkich terenów miejskich z miastem, poprzez likwidację odrębności administracyjno - sądowych.

Problemy związane z kwaterowaniem tu wojska, oraz zadłużenie miasta nie pozwoliły na jego szybką odbudowę. Dawne miejskie zakłady przemysłowe (blech, szlifiernia, postrzygalnia), przestały istnieć. Działała jeszcze woskobojnia, ale była wydzierżawiona. Łaźnie miejskie oraz wodociągi po okresie potopu szwedzkiego nie funkcjonowały. Jedyne prace, na jakie było stać miasto to interwencyjne roboty porządkowe na ulicach i Rynku, remont mostów i Ratusza.

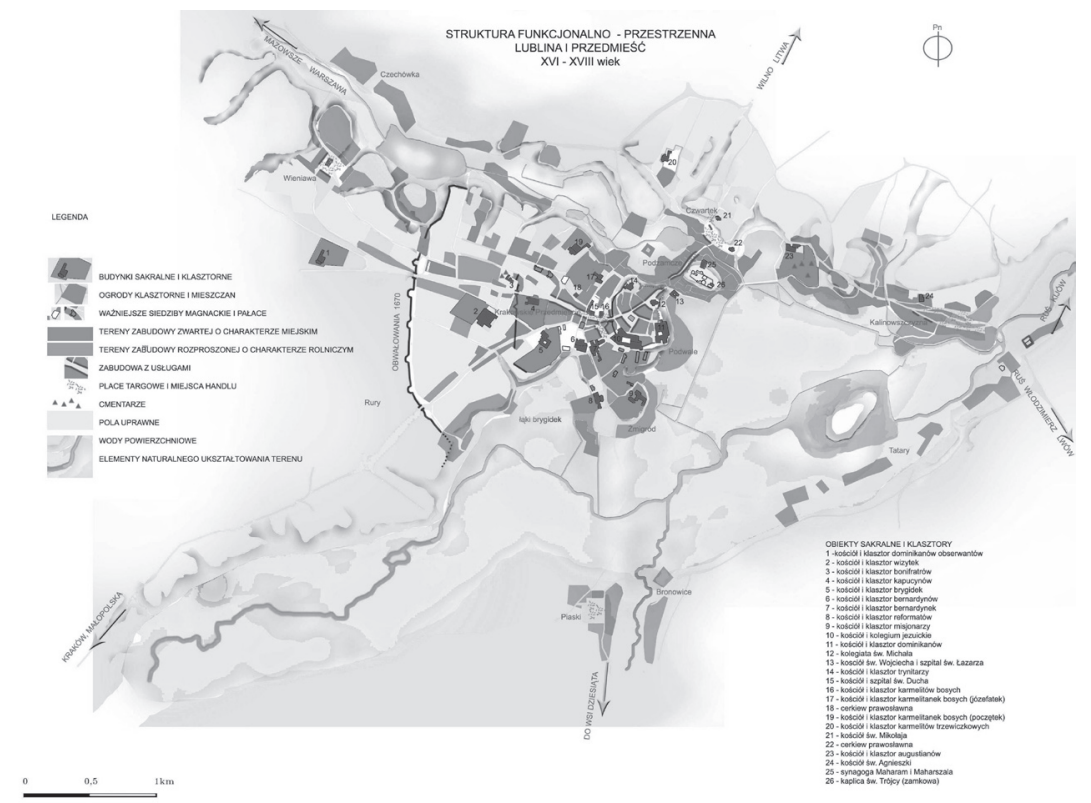

Ryc. 1. Schemat struktury funkcjonalno - przestrzennej Lublina w końcu XVIII wieku. Opracowanie N. Przesmycka

Fig. 1. The scheme of a functional and urban structure of Lublin in the end of XVIII century. N. Przesmycka 
Pod koniec XVIII wieku stan sanitarny i techniczny zabudowy miasta był bardzo zły. W ruinie pozostawały bramy i ratusz, oraz Zamek - dawna siedziba starosty, a w kilku ocalałych izbach mieściła się w nim jeszcze kancelaria ziemska. Dawne pałace, między innymi Potockich, Radziwiłłów, Sapiehów, Sobieskich, Czartoryskich, Lubomirskich, podobnie jak większość klasztorów były opuszczone i zrujnowane.

\section{Działalność Komisji Boni Ordinis}

Lubelską Komisję Boni Ordinis powołał dekret króla Stanisława Augusta z 12 stycznia 1780 roku, [4]. Komisji przewodził ostatni wojewoda lubelski Kajetan Hryniewiecki, [2]. W grudniu 1782 roku zreformowano ustrój władz miejskich. W miejsce czterech burmistrzów zmieniających się na stanowisku prezydenta co kwartał, ustanowiono prezydenta i wiceprezydenta z roczną kadencją. Takie rozwiązanie miało zapewnić lepszą organizację urzędu i większą skuteczność decyzyjną. Do Lublina w końcu XVIII wieku zaczęli napływać nowi kupcy i rzemieślnicy, którzy wkrótce zasymilowali się z miejscową ludnością [6]

Na sesji w dniu 11 V 1784 roku lubelska komisja Boni Ordinis „dla wygody wszystkich mieszkańców, jak też dla utrzymania nawet zdrowia ludzkiego" uchwaliła ordynację względem porządku publicznego, a zwłaszcza spraw sanitarnych. Treść tej uchwały wskazuje na wielkie zaniedbanie, w jakim znajdowało się miasto $[13,14]$. Uchwała regulowała przede wszystkim sprawy zachowania czystości w mieście, oraz sposób w jaki właściciele mieli dbać o otoczenie posesji, a drastyczność sformułowania świadczy o fatalnych warunkach sanitarnych w jakich miasta się znajdowało: "Aby nikt błota $w$ rynsztoki zmiatać lub zgarniać, a tym samym spadek wodzie tamować, śmieci, wiórów, trocin, gruzów, popiołów, obierzyn, słomy, gnojów, fecesów, zdechlin, warzywa zepsutego $i$ innych wszelkich rzeczy ulice szpecacych i zawalajacych na ulicę wyrzucać nie ważyt się. Lecz to wszystko za miasto $w$ miejsca odległe lub $w$ doły wywozić $i$ wynosić każdy starat się, przed czyja by posesja rzecz jakowa nieochedostwo sprawująca znajdowata się, natychmiast, nie wymawiajac się podrzuceniem onej z obcej posesji, też sprzątną́, a podrzucajacego dochodzić ma.(...)Aby nikt nie ważył się wody, pomyj, mydlin, fusów, lagrów i innych rzeczy błoto pomnażajacych i fetor czyniących gdzie indziej wylewać, jak tylko w rynsztoki.(...) Aby nikt zdechlin żadnych na ulicę lub $w$ kanały wyrzucać $i$ wywłóczyć nie ważyt się, a gdyby o to byt przekonany, nie tylko mistrzowi $w$ dwójnasób należytości za wywiezienie zapłaci, ale nadto karze osobowej grzywien 30 do kasy miejskiej podpadnie. [14]

Z przytoczonej uchwały wyłania się obraz miasta brudnego, zaniedbanego i śmierdzącego walającymi się nieczystościami...

W pierwszej kolejności władze miejskie zajęły się regulacją funduszy i finansów miejskich, które znajdowały się w bardzo złym stanie. Wprowadzono nowe podatki: konsumpcyjny, brukowy i kwaterunkowy, wydzierżawiono folwarki miejskie: Ponikwodę i Bronowice. Już w 1786 roku budżet miasta wyrównał się a następne lata przyniosły ponad dwukrotny wzrost dochodów Lublina. Zasobniejsza kasa oznaczała wyraźniejszy postęp w innych dziedzinach.

Inwestycje miejskie z okresu działania Komisji Boni Ordinis dotyczyły poprawy stanu technicznego najbardziej znaczących budynków i części miasta. Wyremontowano, odbudowano bądź przebudowano zabudowę wokół rynku i dawny ratusz. 
Wybrukowane zostały główne ulice, zlikwidowano zawaliska pochodzące jeszcze z XVII wieku. W celu zapobiegania pożarom, Komisja Dobrego Porządku nakazała przeniesienie poza obręb centrum miasta warsztatów używających otwartego ognia, tj. piekarskich, kowalskich i garncarskich.

W wyniku działania Komisji zaczęto odbudowywać zrujnowane gmachy, porządkowano tereny po ruderach. Rynek i ważniejsze ulice otrzymały kanały ściekowe i nowe bruki. Przebudowa ratusza zmieniła drastycznie wygląd i przestrzeń Rynku. W latach 1781-1787 podwyższono drugie piętro budynku i nadano mu nową szatę architektoniczną, wg proj. Dominika Merliniego. Ratusz zdominował rynek, zarówno gabarytami jak i klasycystyczną elewacją.

Dzięki działalności Komisji Boni Ordinis wyremontowano Bramę Krakowską i przebudowano Bramę Grodzką (1785). Bardzo ważna zarówno ze względów sanitarnych jak i przestrzennych było uporządkowanie przedpola murów miejskich. Mury średniowieczne w tym okresie praktycznie już nie istniały, a tereny sąsiadujące z nimi były szczególnie zaniedbane. Problem ten szczególnie widoczny był po północnej stronie Bramy Krakowskiej. W linii równoległej do tego odcinka wytyczono ulicę Nową, biegnącą wzdłuż dawnych murów obronnych, wydzielając „znormalizowane" parcele pod zabudowę. Działki miały szerokość 22 łokci od frontu, a na nabywców nakładano obowiązek ich szybkiej zabudowy [2]. Od końca XVIII do połowy XIX wieku stanął tu rząd kamienic wyznaczający półkolistą linię zasięgu Starego Miasta i ulicę Nową (dzisiejszą Lubartowską).

W latach 80-tych doszło do licznych zmian własnościowych nieruchomości. Prywatne inwestycje budowlane i remontowe były wspierane przez władze poprzez kilkuletnie zwolnienia $\mathrm{z}$ podatków miejskich. Zniszczone rezydencje, pałace i kamienice, wykupywali patrycjusze [4].

W okresie działania Komisji Boni Ordinis został stworzony pierwszy pomiarowy plan miasta, z uwzględnieniem terenów jurydyk i przedmieść. Autorem planu był geometra Jan Nepomucen Łęcki (1781 - 1783), [3].Plan dokładnie obrazuje układ zabudowy i ulic, a także podziały własnościowe gruntów. Poszczególne kopie zachowane do dnia dzisiejszego (oryginał nie jest znany) różnią się nieznacznie, ponieważ kopiści wybierali różne obiekty do oddzielnego oznaczenia i opisania, Ryc. 2 .

Układ sieci drożnej ukazuje miasto jeszcze w okresie, gdy szlak na Warszawę biegł północnym skrajem doliny Czechówki, w sąsiedztwie przedmieścia Wieniawa. Trakt Krakowski przebiegał po południowej stronie kościoła Św. Krzyża i zbiegał się z traktem warszawskim na Placu na Rozdrożu. Na planie widoczne są pozostałości po Wielkim stawie Królewskim - zarówno w nazwie jak i obecności zbiornika wodnego wokół wyspy - „Góry”. Interesujący jest też strumień (częściowo znikający pod ziemią), płynący od Ponikwody przez Kalinowszcyznę. Jest to rzeczka Muchawiec, która wyschła w XIX wieku. Na planie oznaczone są i opisane kościoły, Nieścioruk K., 9] 


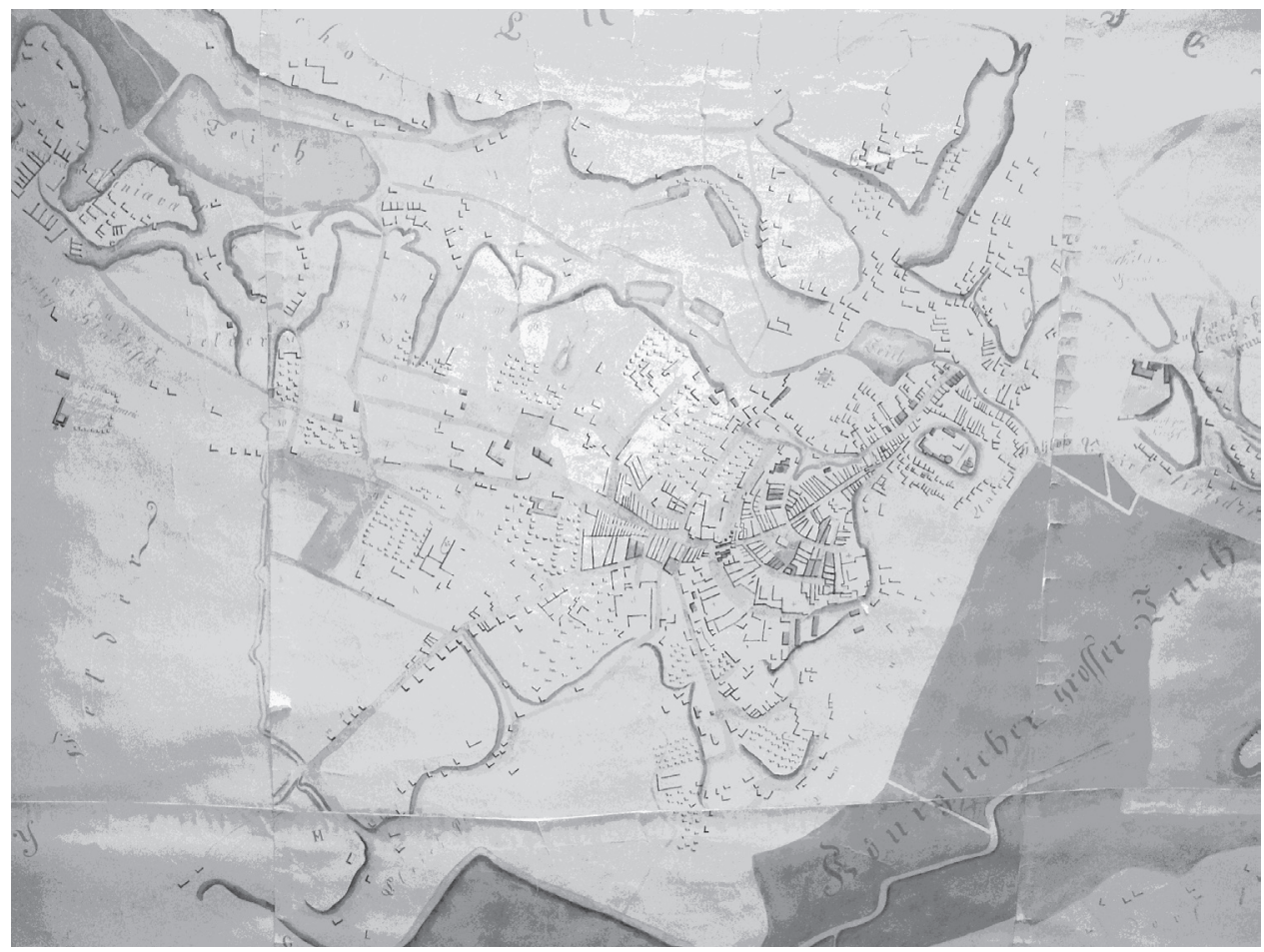

Ryc. 2. Plan Jana Nepomucena Łęckiego z 1784 roku wykonany na potrzeby Komisji Dobrego Porządku, APL, PmL, sygn. 2.

Fig. 2. The plan of Lublin by Jan Nepomucen Łęcki, 1784. Done for the Comission of Boni Ordinis, APL, PmL, sygn. 2.

Otwartość władz na inwestycje sprzyjała powstaniu kościoła ewangelicko augsburskiego. Przywilej z 1784 roku króla Stanisława Augusta umożliwił zbudowanie kościoła wraz z plebanią. Parafię przeniesiono z miasteczka Piaski, [8]. Kościół pw. Świętej Trójcy usytuowano w rejonie Krakowskiego Przedmieścia, przy drodze biegnącej w kierunku Wieniawy, w stosownej odległości od najbliższej świątyni rzymskokatolickiej ${ }^{1}$. Obok kościoła istniały budynki gospodarcze oraz klasycystyczna plebania z kolumnowym portykiem. Przy kościele od 1787 do 1831 roku (kiedy przeniesiono pochówki na cmentarz przy ul. Lipowej), funkcjonował cmentarz przykościelny [1].

W 1790 roku w miejsce Komisji Dobrego Porządku powołano wojewódzką komisję cywilno - wojskową. Komisja składała się z 16 reprezentantów szlachty i 4 duchowieństwa, w 1791 roku dołączyło do niej 3 mieszczan. Na czele komisji stanął ponownie wojewoda Kajetan Hryniewiecki. Komisja ustanowiła uchwałę o sporządzenie szczegółowej taryfy dymów. Zajęto się przede wszystkim poprawieniem bezpieczeństwa $\mathrm{w}$ mieście, poprzez walkę z przestępczością, łapaniem ludzi

${ }^{1}$ „...względem odległości miejsca w budowaniu zborów na łokci dwieście od kościoła rzymskiego katolickiego zachować się powinniej nastąpionego, w tej mierze żądających" - cytat z zaświadczenia o prawidłowej lokalizacji kościoła wydanego przez prezydenta Lublina i Radę Miasta. Kościół zbudowano w stylu klasycystycznym, według projektu architekta Fryderyka Zilcherta alias Zillehera trwała w latach 1785 - 1788. [8]. 
„luźnych” i patrolowaniem miasta przez żołnierzy. Zorganizowanie patroli nastąpiło w porozumieniu z Tadeuszem Kościuszką. Ważna dla przyszłego kształtu przestrzennego miasta była decyzja komisji o przeniesieniu poza miasto miejsc pochówku.

Po likwidacji jurydyk (1791) w 1792 roku miasto zyskało nowy podział terytorialny. Lublin został podzielony na dwa cyrkuły: lubelski i podzamecki. W kwietniu dokonano wyborów władz cyrkułów, a 14 kwietnia wybrano pierwszego konstytucyjnego prezydenta - Teodora Franciszka Gruella - Gretza [4]. Działalność Komisji spowodowała dyskusję o przyłączeniu do miasta terenów dóbr Wieniawy i Czechówki, [11]

Przegrana wojna polsko - rosyjska przerwała urzędowanie nowych władz w mieście już w lipcu 1792 roku. Przez miasto przeszły cofające się wojska księcia Józefa Poniatowskiego. 25 lipca, bez walk, miasto zajęli Rosjanie. Niespełna tydzień później, przedkonstytucyjne władze miasta, przywróciła zawiązana z inspiracji hetmana Branickiego targowicka konfederacja województwa lubelskiego. Działały one na zasadach określonych przez Komisję Dobrego Porządku.

W 1793 roku odbyły się ostatnie w wolnej Rzeczpospolitej obrady sejmu grodzieńskiego. Uznano wówczas Lublin, obok miast takich jak Warszawa, Kraków, Sandomierz i Łuck za miasto główne Korony. Wiązało się to z ponownym potwierdzeniem i utrzymaniem likwidacji jurydyk i zapewnieniem nietykalności osobistej i majątkowej dla mieszczan Postanowiono także, że Lublin miał się stać jedyną stolicą Trybunału dla całego kraju. Wybrano nowe władze miasta, ponownie wybierając na prezydenta Gruella, który jednak tej funkcji nie przyjął [4].

U progu XIX wieku Lublin ciągle był miastem zniszczonym i ekonomicznie podupadłym, jednak działania Komisji Boni Ordinis dały prawne podstawy dla jego dalszego rozwoju, zaś plan pomiarowy wykonany na potrzeby Komisji stał się podstawowym opracowaniem kartograficznym, przerysowywanym i dopracowywanym przez kolejne kilkadziesiąt lat.

\section{Literatura}

[1] Czerepińska J., Michalska G., Studziński J., Zespót kościoła Świętej Trójcy w Lublinie [w:] Parafia Ewangelicko - Augsburska w Lublinie; historia - tradycja - współczesność, (red. ks. dr Dariusz Chwastek), Lublin 2007, s. 55.

[2] Gawarecki H., Gawdzik Cz., Lublin, Krajobraz i architektura, Warszawa 1964.

[3] Gawarecki H., Stankowa M., Stanisław Jan Nepomucen Eęcki IKM i Trybunatu Lubelskiego Geometra Przysięgty, [w:] Studia i materiaty Lubelskie t. 5, Muzeum w Lublinie, Lublin 1971, s.358.

[4] Janas E., Miasto wydziałowe. Lublin u schyłku XVIII wieku [w:] Radzik T., Witusik A. A. (red.), Lublin $w$ dziejach i kulturze Polski, Lublin 2000.

[5] Kalinowski W., Trawkowski S., Przebudowa Lublina w Królestwie Kongresowym w latach 1817-1820, [w:] Ochrona Zabytków, 1954, nr 3, s. 161.

[6] Kermisz J., Lublin i Lubelskie w ostatnich latach Rzeczypospolitej (1788-1794), t. I, Lublin 1939/1945.

[7] Mazurkiewicz J., Jurydyki Lubelskie, Wrocław 1956.

[8] Michalska G., Dzieje parafii ewangelicko - augsburskiej w Lublinie z uwzględnieniem dziatalności w Piaskach Luterskich, [w:] Parafia Ewangelicko - Augsburska w Lublinie; historia - tradycja - współczesność, (red. ks. dr Dariusz Chwastek), Lublin 2007, s. 30. 
[9] Nieścioruk K., Metodyczne aspekty kartograficznej analizy i oceny dawnych planów miast na przykładzie planu Lublina z 1716 roku C. d’Örkena, praca doktorska.

[10] Przesmycka E., Przeobrażenia zabudowy i krajobrazu miasteczek Lubelszczyzny. Lublin 2001, s. 40-41.

[11] Witkowski W., Podlubelska Wieniawa, [w:] Rocznik Lubelski XIV, 1971, s. 159.

[12] Wróbel T., Zarys historii budowy miast, Warszawa 1971.

[13] APL, AmL, Księgi, 179, k. 238-240v, oryginał.

[14] APL, AmL, Księgi, 179, k. 312-314v.

\title{
The commision of Boni Ordinis in Lublin and its impact on spatial development of the city
}

\author{
Natalia Przesmycka ${ }^{1}$, Jerzy Z. Przesmycki ${ }^{2}$ \\ ${ }^{1}$ Chair of Architecture Urban Design and Spatial Planning, Faculty of Civil Engineering and \\ Architecture, Lublin University of Technology, e-mail: natalia.przesmycka@gmail.com \\ ${ }^{2}$ College of Enterprise and Administration on Lublin, e-mail: jerzy.przesmycki@gmail.com
}

Summary: The activity of the Lublin Good Order Committee (Boni Ordinis) was the first that gave measurable results to the action of improvement of the image of city, its administration and regulation issues. The city was destroyed and in economic collapse after the seventeenth century wars. Other activities of the Commission of Boni Ordinis was also a manifestation of social thought and increase of the importance of the middle class in the country.

Key words: Boni Ordinis, spatial development of Lublin. 